American Journal of Economics and Business Administration 1 (2): 122-132, 2009

ISSN 1945-5488

(C) 2009 Science Publications

\title{
Push Vs Pull: Factors Influence Student Retention
}

\author{
Matthew Leone and Robert G. Tian \\ Medaille College, Buffalo, New York, USA
}

\begin{abstract}
Problem statement: Student retention becomes one of the most significant issues that administrators of colleges and universities must deal with in today's highly competitive market. Approach: In fact retaining a student is fundamental to the ability of an institution to carry out its mission. A high rate of attrition is not only a fiscal problem for schools, but a symbolic failure of an institution to achieve its purpose. Results: There are many ways to keep students retain at the same college until graduation, some easier than people may think but great changes will have to be made in order for schools to complete these transformations. This study is a descriptive study about the factors that influence student retention rate at a higher educational institution. Conclusion/Recommendations: Based on the previous studies of the similar topic and a random sample survey, this study identifies the possible push and pull factors that promote student leave from a specific college and transfer to other colleges to continue their college studies, it probes the implementable solutions to help the college to maintain and increase the student retention rate.
\end{abstract}

Key words: Campus life, degree programs, educational administrators, financial aid, student retention

\section{INTRODUCTION}

In today's highly competitive education market, to maintain and increase student retention rate becomes one of the most crucial issues for higher educational institutions to be successful. Student retention involves the way students enroll, stay enrolled, complete their degrees, or drop out at a specific higher education institution. It describes the flow of students through college over a discrete period of time. The significance of student retention has been continuously growing throughout the history of higher education across the country and the administrators have been busy on researching what they can do to help lower the number of students transferring from, or dropping out of, their institutions. Higher education institutions have to spend millions of dollars each year to bring students to colleges or universities and meanwhile they have to see many students leave from their institutions within a single year. Scholarly studies indicate that about $40 \%$ of freshman and sophomores dropping out of college or transferring to other institutions and at the same time about $60 \%$ of all bachelor's degrees are awarded to students who did not started their education at the institutions that grant them the degrees ${ }^{[6,23]}$.

Retention is often described in two different ways: As degree completion versus non-completion and as dropping out versus not dropping out. A variety of reasons were found out by scholarly researches as why students dropped out schools or left their original colleges for new ones, those reasons can be highly summarized into the following categories: Reasons related with financial issues ${ }^{[1,6]}$, reasons related with academic issues ${ }^{[7,24,28]}$, reasons related with campus life issues $^{[19,21]}$, reasons related with campus physical condition issues and reasons with personal issues ${ }^{[4,12]}$. More specifically, Astin ${ }^{[2]}$ suggest that the retention rate of students is greatly affected by the level and quality of their interactions with peers as well as faculty and staff. The emphasis is on the conditions in which the higher education institutions place students rather than on the attributes of students themselves ${ }^{[9]}$.

Tinto $^{[26]}$ reveals the factors in students dropping out include academic difficulty, adjustment problems, lack of clear academic and career goals, uncertainty, lack of commitment, poor integration with the college community, incongruence and isolation. As a result, retention can be highly affected by enhancing student interaction with educational institution staff. It is also found out that student's perception of an institution plays a great role in their retention. Students like to know policies and diverse learning environments are developed for the student to prosper. Campus life plays an important role in facilitating student retention, new students want to feel welcomed, part of a community and confident they made the right choice upon entering college. The emphasis placed on orientation programs, the attitude and interaction of faculty and the campus 
environment can help, or hinder, students through their first year. An institute's first-year retention efforts should also include welcome week, seminars, academic advising, support centers, research possibilities and many more; efforts must be broad-based, coordinated and inclusive of the entire campus ${ }^{[13]}$.

As competition heats up in the education services industry both in the USA and internationally, higher education institutions have become increasingly interested in the perceived affordability of the price of tuition and other associated costs as the means of maintaining and increasing student retention rate. In a number of studies, financial aid has also been shown to play a key role in the college choice process and retention decision ${ }^{[11,17,18]}$. According to Hossler ${ }^{[10]}, 80 \%$ of high school students consider the availability of financial aid an important criterion when making decisions about which college or university to attend. In another study by $\mathrm{Kim}^{[16]}$, different types of financial aid were found to increase the probability of attending firstchoice institutions, particularly for white and AsianAmerican students. Apparently financial aid packages that various colleges designed will not only influence students' choice of a college but also play a crucial role for students maintain and retain at the same college.

An extensive body of research identifies the conditions that best promote retention, in particular during the students' first year of college. Early studies focused on the characteristics of those students who did not persist and such studies were used as evidence for higher admissions standards or more quality control of recruitment. Later research began to concentrate on the reasons students remained enrolled and how higher education institutions could make changes or develop programs to increase the retention of their students ${ }^{[19]}$. One study demonstrates two critical factors in students' decisions to remain enrolled until the attainment of their goals: one is their successfully making the transition to college aided by initial and extended orientation advisement programs, another one is making positive connections with college personnel during their first term of enrollment ${ }^{[22]}$.

Bean $^{[3]}$ argues that there are some important keys for a higher education institution to retain as many students as possible and that these keys to retain students fall in the hands of the institutional administrators. He suggests services such as learning centers (for students that experiencing economic difficulties), freshman year programs (to help students adjust to the campus and a life away from home), peer teaching and tutoring, academic advising, hands on computer labs, career centers (for those afraid of what they may face in the future), study rooms (to help students catch up on work, socialize and conduct group meetings), social and professional organizations (extracurricular activities that help younger students integrate smoothly into a new learning environment) and finally organizations to help manage multiculturalism and diversity.

In a recent article Tinto ${ }^{[27]}$ indicates there are five major means stand out as supportive of retention, namely expectation, advice, support, involvement and learning. With the variety in programs and other physical tools, students should never feel left out in the dark. By supplying the students with those types of corner stones, almost all of the problems they have, can be fixed by using one of the suggested means. Pompper ${ }^{[20]}$ proposes a public relation approach to increase the retention rate at higher education institutions. For Pompper ${ }^{[20]}$ the effective communications among all of an institute's departments, students, alumni, prospective students and the community is essential.

Moreover, the campus itself may project a certain level of academia. Buildings, technology, multipurpose equipment and spaces, student centers and alternative learning communities can help students learn but also improves retention. Spaces that allow students to have discussions, relax and function as a private study area is ideal for student centers ${ }^{[1]}$. Updating social and residential areas to satisfy students' needs is a great way to attract and retain students.

One method that has been thought up of is to encourage high school counselors or administrators to create classes that would help with the transition to college, or have it be one the required classes for a first semester freshman. Institutions might be encouraged to design guidance activities that not only provide specific information, but also teach exploration and decisionmaking kills, as well as promise self-understanding ${ }^{[15]}$. The problem that Kelly and others find with a lot of programs that are created is that they are reactive to retention issues and not proactive in preventing the student from thinking about leaving long before they begin to look outside the school. These ideas have been thought about by other people to fit what they see are issues of their particular institution.

This study, based on the existing research literature body on higher education retention, is primarily a descriptive study according to the data collected from a particular small private college on the factors that influence the retention rate in terms of push and pull forces. The authors attempted to find the solutions as what efforts the college can make without extra cost to maintain and increase the retention rate. Followed this brief literature review is a description about the study process and the methods used in the study, then the 
authors will present the findings from the study followed by some initial analyses and discussions, finally a tentative conclusion and some administrative suggestions will provided for higher educational leadership to consider.

\section{MATERIALS AND METHODS}

This study is originally designed as a term project to the students who registered in Marketing Management and Strategy course at Medaille College in the fall semester of 2008. In the class the students were exposed to the latest findings and theories in marketing management and strategy management. They were trained to accurately and scientifically assess the market needs and to strategically make market plan to meet those needs for better serving an increasingly diverse population. The topics covered in the course include market analysis and measurement, competitive analysis, product strategy, distribution strategy and pricing strategies for domestic and foreign markets. With all that knowledge under their belts the students were then given a term project which entailed conducting a literature review research report and then make an implementable marketing plan based on the first hand data collected through the semester.

The accessible population for this study included all identifiable students who had either dropped from Medaille College or transferred to other colleges from Medaille College since 2005, the total number was estimated to be 900 (the college admission office estimates that every year the college will lose about 300 students). The college is located in Buffalo, New York, just on the outskirts of the city and neighbored with Canisius College, a middle sized private higher education institution. Medaille College is a small liberal arts higher educational institution that has an enrollment of almost 3,000 undergraduate, graduate and professional students from everywhere in the Western New York area and beyond. According the college's official data its current retention rate is about $70 \%$, slightly higher than the current national average retention rate which is $65 \%$. The college's small tight knit community with efficient facilities is a corner stone that draw students to enroll and to stay; however the college administrations believe the retention rates could continuously be increased and thus make it as the one of the primary strategic goals for the college in the next few years.

In total 20 students at their junior or senior years were enrolled in the Marketing Management and Strategy course, the instructor randomly organized those 20 students into five study groups. First the students were directed to conduct a literature review and each student was requested to read and review at least 10 academic papers on maintaining and increasing higher education student retention rates. Based on their literature review each student was requested to write a research report of about 1000 words and then the group members would share their findings and collectively write a literature review report of about 1500 words, which is a synthetically integrating of findings from individual group members. Through the literature review the students realized that in the current highly competitive higher education market, to keep the students to stay for all four years until graduation becomes one of the most important strategic issues for their daily operations and growth, it is especially important for those small private colleges whose operational budget is mainly tuition driven.

Secondly, the students were instructed to design a questionnaire survey as teams and then by a collaboration of all the students and the instructor the questionnaire was refined in the class to be administrable. The questionnaire itself was geared towards the push and pull factors of why students leaving from Medaille College and come to their new colleges. The questionnaire was first developed by individual groups and then it was discussed and refined in the class under the guidance of the instructor. Each individual student was requested to give the inputs and ideas onto what the questions should be included. Since the students had friends who left from the college, they could use the knowledge that they had obtained from their friends to formulate the questions.

The survey included 32 questions and was divided into two sections. The first 10 questions in section one were designed to indentify the factors that influenced the respondents made the decision to leave from Medaille College, these factors are termed as pushing factors by the authors range from educational reputation, degree programs and faculty members to campus life, food service, dormitory conditions and location. Questions 11-20 were designed to identify the factors that drew these respondents to their current colleges from Medaille, these factors are termed as pull factors by the authors included exactly the same as listed in the first 10 questions. Question 21 asked the respondents if their decision to change colleges was influenced by their friends and question 22 asked the respondents to evaluate their decision to change colleges was wrong or not. Section two included 10 questions requesting specific personal information from the respondent. These questions include gender, age, family financial situation, religious background, ethnic background, year and major. A copy of the questionnaire is provided as Appendix A. 
After the survey was completed the students were trained in class by the instructor how to professionally administrate survey. Each student was requested to use his or her personal social network to contact a minimum of seven former students who left Medaille College recently and administrated the survey in person. Since the students personally knew some of their peers who had recently left Medaille College it is not difficult for them in finding target subjects. The students were required to administrate the survey in person rather than mailing the questionnaire to individual respondents because if the respondent had any questions about the questionnaire administrator could immediately explain to them, also by administrating the survey in person made it easier to get more detailed and valid information from the respondents by asking the open ended questions.

In addition to the questionnaire six open-ended questions were developed to be used with those respondents who agreed for an in-depth interview. The first question is to let the interviewees indentify three most important things that made them select their original college and why. The second question asks the interviewees to recall at what critical moment they decided to change the colleges and the reasons. The third question is to let the interviewees indicate who plays the most important role in their decision to change colleges and why. The fourth question asks the interviewees to report three most important things that promoted them to their current colleges and why. The fifth question asks the respondents to report three most important things that pushed them to leave from their original college and why. The sixth question is to let the interviewees to share anything else that they are willing to share with others about their experience of changing colleges. A copy of the in-depth interview questions is provided as Appendix B.

After the surveys were completed and handed in, under the training and supervision of the instructor, 2 students helped to enter the data into spread sheets and created about 200 pivot tables that were distributed to individual groups for analysis. When the data processing was over, the instructor had each group create a marketing plan for Medaille College. Some of the topics to be included in their finished documents were: the marketing challenge analysis, a SWOT analysis, a marketing mix analysis, the expected objectives, a detailed action plan and a contingency plan according to their literature review, the survey outcomes and the results of the in-depth interviews. In addition the students were requested to include what they had learned from doing the term project. This study therefore is an extension of the students' term projects and synthesizes the students' findings with a more academically oriented discussion. Although the contributions from all the students who involved in the class should be clearly acknowledged it is entirely the authors' responsibilities for all the mistakes and limitations.

\section{RESULTS}

Among the final sample of 122 undergraduate students who left Medaille College to other colleges, $56.6 \%$ (69 out of 122) were females and $43.4 \%$ (53 out of 122) were males. The age was normally distributed and identical to the population under study, 36.9\% (45 out of 122) were 20 years old or younger, 53.3\% (65 out of 122) were between 21-25 years old and only $9.8 \%$ (12 out of 122) were 26 years old or older. In terms of marital status the great majority of respondents were unmarried singles, $81.1 \%$ (43 out of 53) of the males and $97.1 \%$ (67 out of 69 ) of the females were singles. Of these subjects $87.7 \%$ (107 out of 122) were enrolled as full time students, $12.3 \%$ (15 out of 122) were enrolled as part time students, $45.9 \%$ (56 out of 122) reported as commute students, $40.2 \%$ (49 out of 122) reported as residential students (Table 1 and 4 for detailed information).

In terms of employment the majority of the respondents had a part time job when studied at colleges, $11.8 \%$ (14 out of 122) worked 1-10 h a week, $32.7 \%$ (40 out of 122) worked $11-20 \mathrm{~h}$ a week, $31.8 \%$ (39 out of 122) worked $21 \mathrm{~h}$ and more per week. No respondents reported as full time employed and $23 \%$ (28 out of 122) reported they were not employed when studied at colleges. It is interesting that $23 \%$ (28 out of 122) respondents claimed they were the first persons in their families to attend colleges. It is also interesting to find out that of those respondents the largest group was majored in business (44 out of 122, 36.1\%), while only a few distributed in each of all other identifiable majors, such as arts, communication, life science, social science, humanity, with 35 out of 122 (28.7\%) reported that their majors are not identifiable in our survey (see Table 2 and 3 for detailed information).

Subjects were asked to select a category that best represented their financial situation. This resulted in the following stratification of respondents: $4.9 \%$ (6 out of 122) upper, $21.3 \%$ upper middle, $52.5 \%$ (64 out of 122) middle, $13.9 \%$ (17 out of 122) lower middle, $4.1 \%$ (5 out of 122) lower and 3.3\% (4 out of 122) did not report their family income status. In terms of ethnicity distribution, the vast majority of respondents, $80.3 \%$ (98 out of 122), were Caucasian, while only $8.2 \%$ (10 out of 122) were African American, 
Am. J. of Economics and Business Administration, 1 (2): 122-132, 2009

Table 1: Survey respondents structure by marital status and ethnicity $(\mathrm{n}=122)$

\begin{tabular}{lllllll}
\hline & Single & Single, head of household & Married & Common law marriage & Divorced & Widowed/widower \\
\hline Male & 43 & 3 & 2 & 0 & 2 & 0 \\
Female & 67 & 0 & 0 & 0 & First nations & 0 \\
& African & Asian/Pacific & Caucasian, & Hispanic & & \\
& American & Islander & Non Hispanic & & 2 & 0 \\
Male & 2 & 2 & 43 & 0 & 1 & 0 \\
Female & 8 & 1 & 55 & 2 & 1 & 0 \\
\hline
\end{tabular}

Table 2: Survey respondents structure by family income and employment $(\mathrm{n}=122)$

\begin{tabular}{llllll}
\hline & Upper & Upper middle & Middle & Lower middle & Lower \\
\hline Male & 5 & 9 & 27 & 8 & 3 \\
Female & 1 & 17 & 37 & 9 & 2 \\
& Not employed & Less than $10 \mathrm{~h} \mathrm{week}^{-1}$ & $11-20 \mathrm{~h}$ week $^{-1}$ & More than $21 \mathrm{~h}_{\text {week }}{ }^{-1}$ & Full time employed \\
Male & 9 & 5 & 19 & 19 & 0 \\
Female & 19 & 9 & 21 & 20 & 0 \\
\hline
\end{tabular}

Table 3: Survey respondents structure by majors $(\mathrm{n}=122)$

\begin{tabular}{lllllllll}
\hline & Arts & Business & Communications & Education & Humanity & Life science & Social science & Other \\
\hline Male & 3 & 12 & 2 & 5 & 1 & 4 & 1 & 15 \\
Female & 2 & 32 & 3 & 3 & 1 & 3 & 2 & 20 \\
\hline
\end{tabular}

Table 4: Survey respondents structure by ages and enrollment status $(n=122)$

\begin{tabular}{|c|c|c|c|c|c|c|c|}
\hline & \multicolumn{3}{|l|}{ By ages } & \multicolumn{2}{|c|}{ By enrollment status } & \multicolumn{2}{|c|}{ By residential status } \\
\hline & $\begin{array}{l}20 \text { years old } \\
\text { and younger }\end{array}$ & $\begin{array}{l}21-25 \\
\text { years old }\end{array}$ & $\begin{array}{l}26 \text { years old } \\
\text { and older }\end{array}$ & $\begin{array}{l}\text { Full time } \\
\text { students }\end{array}$ & $\begin{array}{l}\text { Part time } \\
\text { students }\end{array}$ & $\begin{array}{l}\text { Residential } \\
\text { students }\end{array}$ & $\begin{array}{l}\text { Commute } \\
\text { students }\end{array}$ \\
\hline Male & 23 & 23 & 7 & 43 & 3 & 19 & 26 \\
\hline Female & 25 & 42 & 2 & 64 & 3 & 37 & 23 \\
\hline
\end{tabular}

$4.1 \%$ (5 out of 122) Latino/Hispanic, $2.5 \%$ (3 out of 122) Asian/Pacific Islander, $1.6 \%$ (2 out of 122) First Nations and 3.3\% (4 out of 122) reported as others in ethnicity. Apparently, although ethnicity is a major variable of interest in student retention research, ${ }^{[14]}$ in this study an insufficient sample size among ethnic groups limited the analysis of potential race group effects (Table 1 and 2 for detailed information).

For most students to remain at or to leave from the college they originally enrolled in is a crucial decision to be made based on various factors. According to our initial analysis of the survey data and the result of open ended interviews, there are two categories of forces lead a student to make such a decision, one category we termed as push factors and another category we termed as pull factors. More specifically the push forces are those factors from the original colleges, which neither have the resources to meet individual students' need nor did a good job to satisfy the individual students, accordingly the individual students would be pushed off from their original colleges. While the pull forces are those factors from their current colleges, which either have the resources to meet individual students' need or are able to do a better job to satisfy individual students and thus pull those students to their current colleges from their original colleges.
Table 5: The most significant push forces $(\mathrm{n}=122)$

\begin{tabular}{|c|c|c|c|c|c|c|}
\hline Factors & $\begin{array}{l}\text { Strongly } \\
\text { agree }\end{array}$ & Agree & Neither & Disagree & $\begin{array}{l}\text { Strongly } \\
\text { disagree }\end{array}$ & $\begin{array}{l}\text { Not } \\
\text { sure }\end{array}$ \\
\hline Campus life & 13 & 31 & 23 & 21 & 6 & 3 \\
\hline Financial aid & 11 & 30 & 37 & 31 & 10 & 3 \\
\hline $\begin{array}{l}\text { Degree } \\
\text { programs }\end{array}$ & 13 & 26 & 26 & 38 & 15 & 4 \\
\hline Location & 14 & 18 & 17 & 31 & 13 & 4 \\
\hline $\begin{array}{l}\text { Foodservice } \\
\text { quality }\end{array}$ & 10 & 20 & 45 & 31 & 9 & 6 \\
\hline
\end{tabular}

In this case the most important push forces reported by the survey respondents are the following five factors, namely, (1) the campus life is too boring, (2) the financial aid package is not good enough, (3) the degree programs are limited, (4) the location is not good and (5) the poor quality of food service (Table 5 for detailed information). Students chose colleges for many different reasons, nice campus, good facilities, great faculty and the degree programs they want to major in. The survey data and the result of open ended interviews indicate that campus life at a specific college is a major factor to influence the students whether they would like to stay at that college or not. It is clear that no matter living on campus or being a commuter, students expect a campus life that is full of meaningful and interesting events and activities. Accordingly, it is college administrators' concern how to provide an exciting and diverse array of programs and events to 
keep the students interested and entertained. The survey data demonstrated that 44 out of $122(36 \%)$ students reported that they left the original college because the campus life is boring.

It is undeniable that the impact of the costs of college and student financial support by the college is one of the most important factors that determine the retention rate at specific college, accordingly to provide good financial aid packages to the students, especially to those students come from lower income families, will definitely one effective means to maintain and increase student retention rate. Oppositely, if a college could not provide good financial aid packages to students who are in need the students may have to leave from the college for others who can provide them a better financial support. The survey data suggested that $33.6 \%$ (41 out of 122) respondents agreed that they left Medaille College because of financial aid issues.

With limited knowledge and experience, it is usually difficult for those young students to determine what they would like to do with the rest of their lives, which is particularly true to the freshmen who are just coming out from their high schools. In most cases with the guidance of family and teachers from high schools the freshmen would have already determined what majors they would like to be enrolled in. However, once enrolled at a college, especially after first one or two semesters at a college, they may wish to switch their majors under the influence of their peers or because of the job market changes. The survey data indicate that there were a considerable number of students, 39 out of $122(32 \%)$, agreed that the reason they left Medaille College is due to the limited degree programs.

It is interesting to find out that the location services as a push force made some students leave from the college for other institutions. Twenty-six point two percent (32 out of 122) of the respondents agreed that they left Medaille College because of the location is not good. Medaille College is a landlocked school, a large cemetery is located in its back yard and a busy highway is in the front of college's main entrance, dormitories and housing on each side and the parking space is particularly limited, which generates a strong negative impact to the commute students. Facing constrains of physical location there is no room for expansion except for upwards. Even though living on a nice campus has its perks, some students may like the freedom of being able to walk around campus and not reach the other side within a minute or two.

In a previous study Tian and his students suggest that the food service quality has a great impact on a college's overall operations $^{[25]}$, student retention, as one of the most important issues for the college administration leadership to concern, by no means will not be influenced by it. Medaille College has outsourced its food service to meet students' needs but students have kept complaining through various channels about their concerns of questionable food service quality at the college. In fact the survey data indicate the poor food service quality is the fifth important push forces that promote student to leave, among those 122 surveyed respondents 30 (24.6\%) agreed that they left Medaille College was due to the college's poor food service quality.

It is interesting to find out that the most important pull factors reported by the survey respondents are almost perfectly accordance with the push forces. The most important pull forces reported by the respondents include: (1) the current college offers more degree programs, (2) the current college provides a better financial aid package, (3) the current college's location is better, (4) the current college campus life is diversified and less boring and (5) the current college provides a better food service. The survey data suggest that 57.4\% (70 out of 122) agreed that they transferred to their current colleges from Medaille College was due to their current colleges have more degree programs to meet their needs, $49.2 \%$ (60 out of 122) agreed their current colleges have better financial support packages, $45.9 \%$ (56 out of 122) agreed that the location of their current colleges is better, $37.7 \%$ (46 out of 122) agreed the campus life of their current colleges is not boring and $24.6 \%$ (30 out of 122) agreed that their current colleges provide a better food service to them (see Table 6 for detailed information).

When comparing Table 5 and 6 the data tend to suggest that in terms of degree programs, financial aid, location and campus life the pull forces are stronger than the push forces, while in terms of food service it seems push force is stronger than pull force. For example, in searching for push forces we had 39 respondents agreed that they left Medaille because of the college does not offer the degrees they wanted to major in, but when we look at the factors in pull forces a staggering 70 people agreed that they transfer to their new colleges because they offer the degrees they want to major in.

Table 6: The most significant pull forces $(\mathrm{n}=122)$

\begin{tabular}{llllllc}
\hline Factors & $\begin{array}{l}\text { Strongly } \\
\text { agree }\end{array}$ & Agree & Neither & Disagree & $\begin{array}{l}\text { Strongly } \\
\text { disagree }\end{array}$ & $\begin{array}{c}\text { Not } \\
\text { sure }\end{array}$ \\
\hline $\begin{array}{l}\text { Degree } \\
\text { programs }\end{array}$ & 30 & 40 & 27 & 11 & 5 & 9 \\
$\begin{array}{l}\text { Financial aid } \\
\text { Location }\end{array}$ & 11 & 49 & 33 & 16 & 6 & 7 \\
$\begin{array}{l}\text { Campus life } \\
\text { Foodservice }\end{array}$ & 11 & 39 & 24 & 11 & 3 & 4 \\
quality & 6 & 24 & 45 & 24 & 9 & 6 \\
\hline
\end{tabular}


Am. J. of Economics and Business Administration, 1 (2): 122-132, 2009

Table 7: Mean factor scores by likelihood of push and pull forces

\begin{tabular}{|c|c|c|c|c|c|c|c|c|}
\hline \multirow[b]{2}{*}{ Factors } & \multicolumn{2}{|l|}{ Push } & \multicolumn{2}{|l|}{ Pull } & \multirow[b]{2}{*}{ Diff } & \multirow[b]{2}{*}{$\mathrm{t}$} & \multirow[b]{2}{*}{$\mathrm{df}$} & \multirow[b]{2}{*}{$\mathrm{p}$} \\
\hline & Mean & SD & Mean & SD & & & & \\
\hline Degree programs & 2.77 & 1.30 & 3.44 & 1.44 & -0.66 & -4.190 & 121 & 0.000 \\
\hline Financial aid & 2.93 & 1.19 & 3.18 & 1.26 & -0.25 & -1.967 & 121 & 0.051 \\
\hline Location & 2.76 & 1.42 & 3.41 & 1.27 & -0.65 & -4.670 & 121 & 0.000 \\
\hline Campus life & 3.14 & 1.27 & 3.23 & 1.26 & -0.09 & -0.687 & 121 & 0.493 \\
\hline Food service & 2.77 & 1.20 & 2.61 & 1.33 & 0.16 & 1.252 & 121 & 0.213 \\
\hline
\end{tabular}

The factor of degree programs is listed in paired questions in the survey for both push and pull force and as such we expected an even numbered answers. The survey outcomes tell us in terms of degree programs the pull force is greater than pull force.

To confirm the effects of push and pull forces toward college changes, mean scores were compared for each of the factors. Table 7 shows the means and standard deviations of both push and pull outcomes for each factor pairing. A paired t-test procedure was used to test the difference between push and pull factor scores. The last column of the Table 7 shows the resulting t-statistic with a corresponding p-level. As seen in the Table 7, differences for push and pull forces in terms of degree programs and location were statistically significant and lend support the suggestion that pull forces are stronger than pull forces. The outcomes of the other three paired factors were not statistically significant to confirm the suggestion that one type of forces is stronger than another one. Apparently, in this case the difference between their original college and current colleges in terms of these two factors, namely degree programs and location, is the key issue for the college administration to seriously concern.

\section{DISCUSSION}

It is clear that when a college cannot satisfy their students' academic needs the students will definitely select to leave for those colleges that can meet their academic needs. The real business world is rapidly changing and with a limited background in a general degree it is hard to get a job in a specified field. Even though the variety of courses offered in certain degree programs is helpful, when individual graduates apply for a job without enough knowledge in specified subject area could be a deciding factor on whether or not one will get the job, given the factor that most new graduates are lack of experience and knowledge in that field.

When analyzed the outcomes of the survey, one phenomenon attracted our attention, in terms of family income, 5 out of $8(62.5 \%)$ African American respondents reported that they were coming from lower class families, while only 7 out of 97 (7.2\%) Caucasian respondents reported they were coming from lower class families. We assumed that family income level, ethnicity, gender, age, enrollment status (full time Vs part time; residential Vs commute), major and employment (employed vs. not employed) are some key variables in assessing student retention rate. We compared means scores of both push and pull forces with each of these variables and assumed there is no significant difference if the mean score difference is less than 0.7 (Table 8 for detailed information).

We found that in terms of gender, residential status, employment status, there is no great difference in mean scores for those variables in the four most reported factors both for push and pull forces. In terms of age, those respondents who were over 20 years old and younger reported that in push force they care more about campus life, degree programs and location, in pull force they care more about campus life and location than those who were over 26 years old. While those who were over 26 years old reported they care more in push force about financial aid than other aged groups. In terms of enrollment status those enrolled as part time had a higher mean score in push force of financial aid factor while those enrolled as full time students had a higher mean score in pull force of location factor. In terms of marital status, those married had higher means cores in financial aid factor for push force and degree programs and financial aid factors for pull forces; while those singled students had higher mean scores in campus life, degree programs and location factors for push forces and in location factor for pull force. In terms of family income levels, those students from upper and upper middle families had a higher mean score in location factor for push force and higher mean score in location and financial aid factors for pull forces, while those from lower income families had a higher score in campus life factor for pull force. In terms of major due to the sample limitation we were only able to compare the business majored students and other majors that were not listed in the survey, except for the factor of campus life factor for pull force, 
Am. J. of Economics and Business Administration, 1 (2): 122-132, 2009

Table 8: Mean scores of various variables for push/pull forces

\begin{tabular}{|c|c|c|c|c|c|c|c|c|}
\hline \multirow[b]{2}{*}{ Variables } & \multicolumn{4}{|c|}{ Push forces } & \multicolumn{3}{|c|}{ Pull forces } & \multirow[b]{2}{*}{ Location } \\
\hline & Campus life & Degree programs & Financial aid & Location & Campus life & Degree programs & Financial aid & \\
\hline Male & 3.060 & 2.755 & 2.960 & 2.645 & 3.340 & 3.978 & 3.478 & 3.638 \\
\hline Female & 3.375 & 2.926 & 3.058 & 3.104 & 3.741 & 3.500 & 3.308 & 3.559 \\
\hline 20 and younger & 3.333 & 2.914 & 2.958 & 3.297 & 3.533 & 3.587 & 3.738 & 3.826 \\
\hline $21-25$ y old & 3.258 & 3.238 & 2.887 & 2.566 & 3.467 & 3.711 & 3.497 & 3.419 \\
\hline 26 and older & 1.600 & 1.600 & 4.200 & 2.400 & 2.333 & 4.250 & 4.411 & 2.750 \\
\hline Full time & 3.298 & 2.913 & 2.971 & 2.940 & 3.504 & 3.732 & 3.407 & 3.653 \\
\hline Part time & 3.166 & 2.666 & 4.000 & 2.500 & 3.200 & 3.333 & 2.833 & 2.833 \\
\hline Residential & 3.240 & 2.785 & 3.194 & 3.481 & 3.346 & 3.584 & 3.407 & 3.648 \\
\hline Commute & 3.362 & 2.935 & 2.804 & 3.522 & 3.659 & 3.800 & 3.348 & 3.638 \\
\hline Single & 3.280 & 3.188 & 3.018 & 2.990 & 3.504 & 3.725 & 3.404 & 3.657 \\
\hline Married & 1.000 & 1.500 & 4.500 & 1.000 & 3.000 & 5.000 & 5.000 & 2.000 \\
\hline Upper & 3.200 & 2.500 & 2.166 & 2.667 & 3.000 & 3.833 & 3.167 & 3.167 \\
\hline Upper middle & 3.231 & 2.923 & 3.000 & 3.000 & 3.800 & 4.042 & 3.720 & 3.840 \\
\hline Middle & 3.234 & 2.875 & 3.000 & 2.854 & 3.306 & 3.541 & 3.226 & 3.476 \\
\hline Lower middle & 3.357 & 2.500 & 3.667 & 3.333 & 3.769 & 3.643 & 3.214 & 3.857 \\
\hline Lower & 3.000 & 3.000 & 2.600 & 2.000 & 4.000 & 3.500 & 2.750 & 3.000 \\
\hline African American & 3.778 & 3.333 & 3.444 & 3.889 & 3.333 & 3.200 & 3.300 & 3.800 \\
\hline Asian & 2.000 & 3.333 & 2.333 & 2.333 & 2.333 & 2.667 & 2.667 & 3.000 \\
\hline Caucasian & 3.145 & 2.833 & 2.979 & 2.708 & 3.489 & 3.800 & 3.391 & 3.527 \\
\hline Hispanic & 4.000 & 2.750 & 4.250 & 3.750 & 4.000 & 3.250 & 3.750 & 4.250 \\
\hline First nation & 4.500 & 3.000 & 2.500 & 2.000 & 3.000 & 1.500 & 2.500 & 3.500 \\
\hline Arts & 2.750 & 2.800 & 3.400 & 2.200 & 3.600 & 4.400 & 3.800 & 3.600 \\
\hline Business & 3.452 & 2.619 & 3.071 & 3.000 & 3.725 & 3.447 & 3.390 & 3.707 \\
\hline Communication & 2.800 & 2.800 & 3.400 & 2.400 & 4.000 & 3.500 & 4.000 & 3.250 \\
\hline Education & 3.571 & 2.714 & 2.857 & 2.667 & 3.250 & 3.875 & 2.875 & 3.125 \\
\hline Humanity & 3.500 & 3.000 & 3.500 & 4.000 & 2.000 & 4.500 & 2.000 & 4.500 \\
\hline Life science & 3.143 & 2.571 & 3.714 & 3.000 & 3.714 & 4.143 & 3.571 & 3.571 \\
\hline Social science & 2.667 & 2.667 & 3.000 & 2.333 & 4.000 & 3.333 & 3.333 & 4.000 \\
\hline Other majors & 3.228 & 2.942 & 2.743 & 2.911 & 3.029 & 3.743 & 3.176 & 3.400 \\
\hline Employed & 3.141 & 2.858 & 3.021 & 2.756 & 3.303 & 3.786 & 3.889 & 3.829 \\
\hline Not employed & 3.615 & 2.884 & 2.740 & 3.423 & 3.840 & 3.375 & 3.320 & 4.031 \\
\hline
\end{tabular}

in which the business majored students had a higher mean score, there is no significant differences in the rest factors for both push and pull forces.

Although ethnicity is usually treated as an important variable in assessing college choice and student retention $^{[5,8,18]}$, due to the sample limitation we assumed that in this case study the data collected in relation to ethnicity is not suitable for further analysis as a variable. As indicated earlier, the sample does mirror the population of Medaille College, the student body is becoming more diversified and the numbers of African American students are growing rapidly. As such, it is expected that in the near future ethnic background will become another key issue for the college administrations to concern in remaining and increasing student retention rate.

The data collected through open-ended interviews confirmed most findings through the survey data. The first open-ended question was to let the interviewees indentify three most important things that made them select their original college, the location of the school (25), the athletics (24), the educational programs (20) and the financial support (8) were mostly frequented factors. The second open-ended question asked interviewees to indicate the critical moment that they decided to change colleges. The three time periods that had the highest responses were: end of the second semester of their freshmen year (64), the sophomore year (40) and end of the first semester of their freshmen year (20). This finding confirmed the previous findings that the first three semesters are crucial in terms of student retention at the original college. The third openended question was to let interviewees recognize who played the most important role in their decision to change colleges, the great majority reported that themselves (64) followed by parents (30).

The 4th question asked the interviewees what were the three most important things that prompted them to enroll in their current college/university. This question is similar to the first question that was asked, but we decided to do this because we thought we could get different results out of the students if we worded the question differently. The most frequently reported factors were: Education programs (27), the location of the school (23), the cost of the school (21) and the size of the school (11). The fifth question asked the 
interviewees to recall the three most important things that prompted them to leave from their original college. The most frequented answers were: the higher cost of the school (28), the lack of degree programs (20), the boring campus life (11) and their disappointed academic progress (11). The last question asked if there were anything else the interviewees would like to tell the interviewer about changing schools, most interviewees did not respond to this question (57), the personal preference was one most frequented answer (24), followed by bad experience at the original college (8), the original college needs to improve educational programs (8) and the original college should provide a better financial support (8).

\section{CONCLUSION}

Student retention is a very serious issue for higher educational administration to concern. For a higher educational institution to be prospering and to be recognized it is necessary to have a well established student population who come in their freshmen year and stay at the same institution until they graduate. To be serious about student attrition, institutions need recognize that the roots of attrition lie not only in their students and the situations they face, but also in the very character of the educational settings, now assumed to be natural to higher education, in which they ask students to learn ${ }^{[26,27]}$. Usually it is hard to specify certain problems for an institution on why students leave their college for others. As found in this case study the campus life, degree programs, financial aid, food service and location may function as push forces that promote their students to leave for other institutions, but these factors may not applicable to other institutions.

Students left their original institution could also be the outcomes of pull forces from its competitors, such as the factors identified in this case study that drew Medaille College students to various other institutions. It is interesting to find out in this case that the pull forces had the similar factors in push forces, although in certain factors one kind of force is stronger than the others, the results are the same: Students left their original college for their new ones. In fact, push and pull forces are relative, given the pull forces, the smaller the push forces the fewer students to leave; vice versa, given the push forces, the stronger the pull forces the more students to leave.

As to Medaille College, it is strongly suggested that the push forces to be reduced. More specifically, the college's administrators need to seriously consider improving the campus life by providing more opportunities for the students to involve in larger social activities and entertainment. Although the location of the college is a given and there is limited space for the college to expend physically, there still have some ways to improve, such as to negotiate with the Canisius College to open a formal side door from the Main Street to the college, to let the lower classes concentrate on Monday, Wednesday and Friday, to let the higher classes concentrate on Tuesday and Thursday and open the evening classes, so that the parking problem can be solved.

It is also suggested that the college's administrators need seriously consider adding concentrations in certain programs. For example of the 122 survey respondents there are 44 students majored in business. At current time the only concentration that Medaille business program offers is management, due to the lack of other popular concentrations in business education, those students who want to major in business with concentrations of marketing, finance, or international business, would have to leave for other colleges even if they love everything else about the college. Apparently, Medaille College needs to expand its concentrations in its popular programs so that it can attain and retain more students. The faculty resource at Medaille College is sufficient to offer these concentration courses and therefore it is easy for the college to reduce the push force in terms of degree programs.

The higher cost is clearly a push force. In today's highly competitive educational market, some of the more prestigious colleges and universities have changed their financial aid policies to allow students from low income families to attend these high cost, elite institutions. Other institutions have updated their facilities to better meet the needs from an increasingly diverse student population. As a tuition driven budgeted small private higher education institution Medaille College does have limited resources to offer a competitive financial aid package to its students, but that does not mean there is no way for the college to lower its cost in operations. By offering online classes and larger classes, the college will be able to lower the cost per course and in turn charge a lower tuition for the students who choose to register for larger classes and online classes.

Finally, we would like to address the limitations of the study and provide some suggestions for the future research. As we demonstrated, this study is based on a term project by the undergraduate students; the data collected are mainly from one particular educational institution and therefore may limit the generalizability of the findings. Nonetheless, there is no reason to believe that the choice dynamics associated with 
students from this sample will not be found elsewhere. Moreover, we should have the opportunity to use more inferential statistics, such as correlations among the key variables, to analyze our survey data. This limitation of course may affect the validity of the study and should be improved in the future study. For the future study we would suggest that another sample should be selected from the current Medaille College student body and the inferential statistics method should be used more widely to analyze survey data. In addition, the instruments used should be refined to reflect the previous and current findings with an emphasis on the assessment of what role faculty plays in student's attitudes toward educational programs and its influence on the student retention.

\section{REFERENCES}

1. Adams and L. Ruth, 2005. Financial literacy and retention.

http://www.pacrao.org/docs/resources/writersteam/ FinancialLiteracyandRz=true\&_\&ERICExtSearch_ SearchValue_0=EJ701984\&ERICExtSearch_Searc hType_0=no\&accno=EJ701984

7. Devonport, T.J. and M.L. Andrew, 2006. Relationships between self-efficacy, coping and student retention. Soc. Behav. Person. Int. J., 34: 1-8. http://findarticles.com/p/articles/mi_qa3852/is_200 601/ai_n17170161/

8. Hamrick, F.A. and F.K. Stage, 2004. College predisposition at high-minority enrollment, lowincome schools. Rev. Higher Educ., 27: 151-161. http://www.eric.ed.gov/ERICWebPortal/custom/po rtlets/recordDetails/detailmini.jsp?_nfpb=true\&_\& ERICExtSearch_SearchValue_0=EJ712263\&ERIC ExtSearch_SearchType_0=no\&accno=EJ712263

9. Hermanowicz, J.C., 2007. Reasons and reasoning for leaving college among the academic elite: Case study findings and implications. J. College Student Retention., 8: 21-38.

http://eric.ed.gov/ERICWebPortal/custom/portlets/ recordDetails/detailmini.jsp?_nfpb=true\&_\&ERIC ExtSearch_SearchValue_0=EJ738876\&ERICExtS earch_SearchType_0=no\&accno=EJ738876

10. Hossler, D., 2000. The Role of Financial Aid and Enrollment Management. In: The Role of Financial Aid in Enrollment Management, Loomes, M. (Ed.). New Directions in Student Affairs, Jossey-Bass, San Francisco, ISBN: 978-0-7879-5378-2, pp: 110.

11. Hossler, D., J. Schmit and N. Vesper, 1999. Going to College: How Social, Economic and Educational Factors Influence the Decisions Students Make. Johns Hopkins University Press, Baltimore, ISBN: 9780801860003.
12. Hoyt, J.E., 2004. Understanding retention and college student bodies. NASPA. J., 41: 395-417. http://publications.naspa.org/naspajournal/vol41/iss3/art1/

13. Hunter and M. Stuart, 2006. Fostering student learning and success through first-year programs. Peer Rev., 8: 4-7. http://ampstools.mit.edu/tomprofblog/archives/2006/09/742_f ostering_s.html

14. Keels, C.L., 2004. Keeping students afloat. Black Issues Higher Education., 21: 32-39. http://www.diverseeducation.com/artman/publish/a rticle_4072.shtml

15. Kelly, J.T., M.K. Marla, R.A. Newgent and C.J. Lucas, 2007. Strategies for student transition to college: A proactive approach. Coll. Student J., 41: 1021-1035. http://eric.ed.gov/ERICWebPortal/custom/portlets/record Details/detailmini.jsp?_nfpb=true\&_\&ERICExtSearch_S earchValue_0=EJ816824\&ERICExtSearch_SearchType - $0=$ no\&accno $=$ EJ816824

16. Kim, D., 2004. The effect of financial aid on students college choice. Res. Higher Educ., 45: 43-70. DOI: 10.1023/B:RIHE.0000010046.57597.43

17. McDonough, P.M., 1997. Choosing Colleges: How Social Class And Schools Structure Opportunity. Albany, State University of New York Press, New York, ISBN: 0791434788, pp: 188.

18. Lillis, M. and R. Tian, 2008. The impact of cost on college choice: Beyond the means of the economically disadvantaged. J. College Admission., 200: 4-14. http://www.nacacnet.org/ PublicationsResources/Journal/Index/Pages/Colleg eCost.aspx

19. Nutt Charlie L., 2003. Academic advising and student retention and persistence. NACADA Clearinghouse of Academic Advising Resources. http://www.nacada.ksu.edu/Clearinghouse/Advisin gIssues/retention.htm

20. Pompper, D., 2006. Toward a relationship-center, approach to student retention in higher education. Pub. Relat. Q., 51: 29-36. http://www.highbeam.com/doc/1P3-1213240321.html

21. Raley, Y., 2007. Why we quit? Sci. Am. Mind, 18: 74-79.

http://www.sciamdigital.com/index.cfm?fa=Produc ts. ViewIssuePreview\&ARTICLEID_CHAR=0952 EA81-3048-8A5E-1071DA22D3D027F0

22. Rendon, L.I., 1995. Facilitating Retention and Transfer for the First Generation Students in Community Colleges. Paper presented at the New Mexico Institute, Rural Community College Initiative, Espanolo, NM. http://www.eric.ed.gov/ERICWebPortal/custom/po rtlets/recordDetails/detailmini.jsp?_nfpb=true\&_\& ERICExtSearch_SearchValue_0=ED383369\&ERI CExtSearch_SearchType_0=no\&accno=ED383369 
23. Shay, M., 2007. Innovative ways to improve undergraduate retention.

http://www.eduinsight.com/retaining_students/imp roving_undergrad_retention.php

24. Suhre, C., 2007. Impact of degree program satisfaction on the persistence of college students. Higher Educ., 54: 207-226.

25. Gramling, L, R. Byrd, L. Epps, D. Keith, R. Lick and R. Tian 2005. Foodservice Management and Its Impact on College Operations: A business anthropological case study. Foodservice Research International, 16 (2005) pp. 15-43.

26. Tinto, V., 1994. Leaving College: Rethinking the causes and cures for student attrition. Chicago, IL: University of Chicago Press. ISBN10:0226804496, 312 pages.
27. Tinto, V., 2006. Taking student retention seriously. Maricopa Community College.

http://www.mcli.dist.maricopa.edu/fsd/c2006/docs/ takingretentionseriously.pdf

28. Zajacova, A., L. Scott and E. Thomas, 2005. Selfefficacy, stress and academic success in college. Res. Higher Educ., 46: 677-706. http://eric.ed.gov/ERICWebPortal/custom/portlets/ recordDetails/detailmini.jsp?_nfpb=true\&_\&ERIC ExtSearch_SearchValue_0=EJ735941\&ERICExtS earch_SearchType_0=no\&accno=EJ735941 